\title{
Will Workers be Unemployed Because of Robots? A Meta- Analysis on Technology and Employment
}

İbrahim DA $\breve{G L I}$ (https://orcid.org/0000-0001-8199-821X), Süleyman Demirel University, Turkey; mribrahimdagli@gmail.com

\section{Çalışanlar Robotlar Yüzünden İşsiz mi Kalacak? Teknoloji ve İstihdam Üzerine Bir Meta-Analiz Çalışması}

\begin{abstract}
The purpose of this paper is twofold. The first is to present an overall effect size of technology's impact on employment. The second is to provide an example of the usability of the metaanalysis method in economics. This study conducted with the meta-analysis method concluded that technology positively affects employment, and the overall effect size is medium ( $g=0.53)$. Contrary to the general prejudice that technology can cause unemployment, it has been concluded that technology affects employment positively. Unlike the other empirical studies, a more comprehensive and general result was obtained thanks to meta-analysis.
\end{abstract}

Keywords $\quad: \quad$ Technological Unemployment, Meta-Analysis, Technology and Employment, Robots and Labour, Future of Work.

JEL Classification Codes: $\quad$ L0, O3, J2.

Öz

Bu çalışmanın amacı iki yönlüdür. Birincisi, teknolojinin istihdama etkilerine dair genel bir etki büyüklüğü sunmaktır. İkincisi, meta-analiz yönteminin iktisat biliminde kullanılabilirliğine dair bir örnek sunmaktır. Meta-analiz yöntemiyle yapılan bu çalışmada teknolojinin istihdam üzerinde pozitif bir etkisi olduğu ve genel etki büyüklüğünün orta düzeyde $(\mathrm{g}=0,53)$ olduğu sonucuna ulaşılmıştır. Teknolojinin işsizliğe neden olabileceğine dair genel önyargının aksine teknolojinin istihdamı olumlu yönde etkilediği sonucuna ulaşılmıştır. Bu çalışmada diğer ampirik çalışmalardan farklı olarak meta-analiz sayesinde daha kapsamlı ve genel bir sonuç elde edilmiştir.

Anahtar Sözcükler $\quad$ : Teknolojik İşsizlik, Meta-Analiz, Teknoloji ve İstihdam, Robotlar ve İşgücü, İşin Geleceği. 


\section{Introduction}

Since the first industrial revolution, the fear that technology will adversely affect work life has been an ongoing debate. The possibility of machines replacing human labour was central to the discussion. Is technology an illness of the century as technological unemployment, as Keynes said in 1930, or does it contribute to human well-being? While the productivity-enhancing effect of technology is noticeable, the impact of technology on employment is still ambiguous. On the one hand, technology increases productivity lowers the cost of goods and services, and creates new industries related to the technology itself.

On the other hand, human labour is being replaced with the job-saving effect, and some workers are losing their current jobs. The skill needs of new sectors and the job descriptions of new professions will be different from today. But the crucial point is whether it will be possible to find a new job for all workers who lost their jobs due to technological innovations. In other words, will there be more newly created jobs than destroyed? If so, that means there will be no unemployment, at least due to technological advances.

It is seen that classical economists also included their views on the economic effects of technology in their famous works. Adam Smith stated the division of labour and specialization and their impact on productivity in his notable work "The Wealth of Nations" (Smith, 1776). Ricardo touched on the mechanization and changing skill requirements, and he claims those would decrease the need for labour over time (Ricardo, 1817). Karl Marx argued that capitalist powers would benefit from the increased efficiency in the manufacturing industries (Bimber, 1990). Keynes spoke of it as a new huge illness in 1930, as if Ricardo and Marx had never discussed it before (Campa, 2018: 34). The first significant action that broke out exactly 21 decades ago in Nottingham was the technology and employment debate milestone. Textile workers tore down the machines in England and started the Luddism movement.

Solow claimed that the technology is an exogenous factor and called the unexplained increased productivity effect "Solow Residual". Even though the idea that workers would lose their jobs was prevalent during the first mechanization years (Leontief, 1979), opposing views emerged after technology created new jobs. Schumpeter introduced the concept of creative destruction and said that technology transforms into new ones while destroying the old ones (Schumpeter, 1943: 81-86). Schumpeter accepted innovation as "a change in the production function" in the production process (Schumpeter, 1939: 84).

International Labor Organization [ILO] (2018) points to a technology-based job polarization around the world. New occupations emerging with new technologies have also transformed the nature and conditions of jobs by changing skill requirements and traditional business models. Technological changes have been dynamic processes that create and destroy jobs and transform how existing jobs are organized (ILO, 2016). The inequality in the distribution of employment due to rural-urban differences and technological transformations may become even more severe in the future (ILO, 2020: 13). ILO (2021) 
expects a globally uneven economic recovery in 2021, but the projected employment growth seems insufficient to close the gaps opened up by the COVID-19 crisis.

The impact of technology on employment has been discussed in many empirical studies in the literature. However, unfortunately, a generally accepted result could not be reached in studies conducted, especially at the macro level. The employment-increasing effects of product innovation, $R \& D$ and patents, and the effects of process innovation on job-saving are evident in the literature. However, most of these studies are sector-level or firm-level research. Naturally, the results vary according to the sample group, and it is complicated to make a macro policy with these studies.

Using the meta-analysis method, this study used a new analysis with empirical studies published between 2010-2021 following the specified criteria. Meta-analysis is a quantitative method that allows combining the results of more than one study into a single result. This method reveals the overall effect between studies regardless of the results of the original studies. On the one hand, no study presenting a general effect on technology and employment relationship could be found in the literature. On the other hand, it has been observed that meta-analysis studies are mainly focused on medicine and educational sciences (Delgado et al., 2018: Kim et al., 2021), and the use of this method is limited in economics (Dagli \& Karacadir, 2021: Yaman, 2020).

Dagli \& Karacadir (2021) researched the relationship between high-technology export and economic growth using meta-analysis. Likewise, Yaman (2020) used a metaanalysis to analyse the relationship between R\&D and economic growth. Using a metaanalysis gives an excellent opportunity to see the general effect in economic studies. For this reason, in this study, using the meta-analysis method, a general effect size on the relationship between technology and employment is presented. In this way, it is aimed to make a concrete contribution to the technology-unemployment debate that has been going on for more than a century from the perspective of the big picture. In the first part of the study, empirical studies available in the literature are included. In the next section, the meta-analysis process and its findings are shared.

\section{Empirical Literature Review}

After the 2000s, many bestseller books dealt with the effects of technology and the relationship between humans and technology. Authors of these books include professors and futurist scientists from renowned universities such as MIT. Some examples of well-known are:

"The Rise of the Robots", Martin Ford (2015); "The Second Machine Age", Eric Brynjolfsson \& Andrew McAfee (2014); "Digital is Destroying Everything", Andrew Edwards (2015); "Still Think Robots Can't Do Your Job", Ricardo Campa (2018); "Smarter Than Us: The Rise of Machine Intelligence", Stuart Armstrong (2014); "Technology vs. Humanity", Gerd Leonhard (2016); "The Inevitable", Kevin Kelly (2016); "The Fourth 
Industrial Revolution", Klaus Schwab (2016); "The Age of Spiritual Machines", Ray Kurzweil (1999).

The literature is divided into two levels as firm-level (micro) and country-level (macro) studies. Some of the micro-level studies are firm-level studies, and the other part consists of sector-level studies.

There are very few macro-level studies dealing with the effects of technological change on employment. In most macro-level studies, the relationship between technology and employment is non-significant or uncertain (Sinclair, 1981; Simonetti et al., 2000; Tancioni \& Simonetti, 2002). Cang (2017) and Evangelista et al. (2014) found that technology and employment are unrelated. Sometimes the results depend on the country as Vivarelli (1995) found the employment effect negative for Italy and positive for the USA. According to Pini (1995), Simonetti et al. (2000), and Feldmann (2013), the effect of the technology was temporary, and it was minimal, according to Krousie (2018) and Aguilera \& Barrera (2016).

When looking at the studies at the micro-level, it is seen that the results are more precise. Significantly, the results are more evident in micro studies conducted according to the type of innovation. The positive effect of product innovation was confirmed in many studies (Evangelista \& Vezzani, 2011; Greenan \& Guellec, 2000; Hall et al., 2008; Lachanmaier \& Rottman, 2011; Meriküll, 2008; Smolny, 1998). However, the impact of process innovation on employment was negative in most studies (Dachs \& Peters, 2014; Falk, 2015; Harrison et al., 2014; Kwon et al., 2015; Van Reenen, 1997).

It is also evident in sector-level studies that product innovation had a positive and process innovation harmed employment (Autor \& Dorn, 2013; Aubert-Tarby et al., 2017; Bogliacino \& Pianta, 2010; Cirillo et al., 2018; Huo \& Feng, 2010; Peters, 2005; Piva \& Vivarelli, 2018). Morrison Paul \& Siegel (2001) found a negative impact of technology on employment in the manufacturing industry. Likewise, Acemoglu \& Restrepo (2020) found the job-saving effect of innovation in local labour markets, and Evangelista \& Savona (2002) confirmed the negative effect in the service industry.

In the studies related to the impact of automation, Frey \& Osborne (2017) found that nearly half of the employment in the U.S. is at risk of automation. Arntz et al. (2016) found this risk $9 \%$ for OECD countries, and Chang \& Huynh (2016) found 3/5 of jobs are at risk of automation in ASEAN countries. World Economic Forum (WEF, 2017) found the ratio of the risk of automation for Morocco and Turkey (50\%), Bahrain and Saudi Arabia (46\%), Egypt (49\%), and Qatar (52\%), UAE (47\%) and Kuwait (41\%). Acemoglu and Restrepo (2020) found that using an additional robot per thousand workers reduces the employment/ population ratio by about 0.2 percentage points (about 400 thousand jobs for the USA). 


\section{Methodology}

\subsection{Data Selection and Collection Processes} follows:

Inclusion and exclusion criteria of the studies included in the meta-analysis are as

- The study should be about the relationship between technology and employment,

- The study should be either an article paper or working paper,

- The study should be published formally from the year 2010-2021,

- The study should be in English,

- The study should include an empirical analysis,

- The statistical data of the study should include $\mathrm{n}, \mathrm{S}$, and $\overline{\mathrm{x}}$ to calculate an effect size.

A preliminary literature review was made to identify the studies required for the meta-analysis. After a premise work, it was determined to search Google Scholar and Scopus database. The search keywords were selected as " $R \& D$ OR patent OR technology AND employment" and "impact of technology' OR 'effects of technology' AND employment". The studies meeting these criteria in "abstract, title or keywords" were selected for the analysis.

Figure: 1

Prisma Flow Diagram

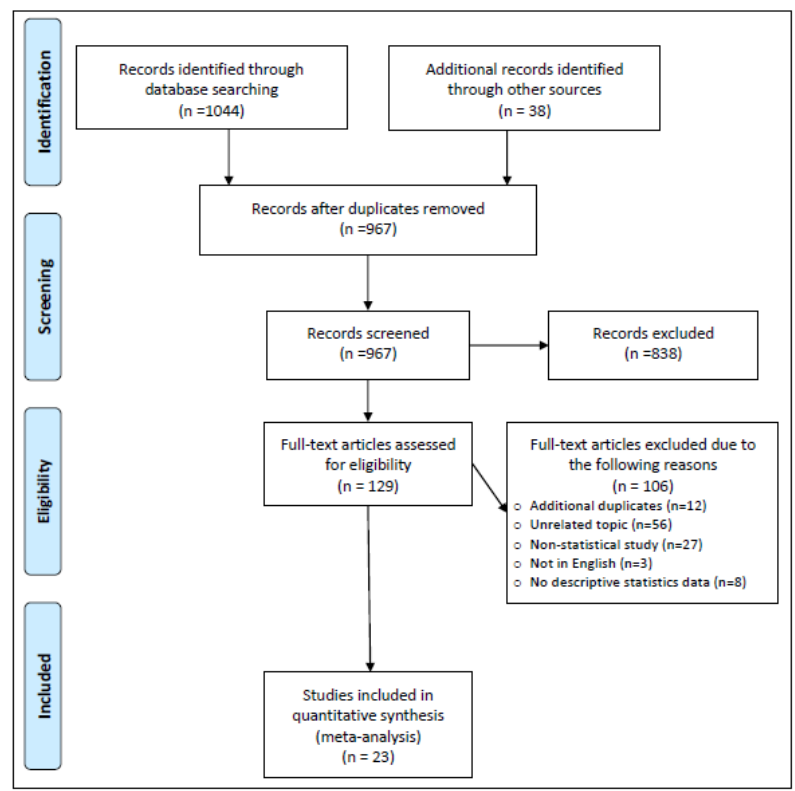


758 studies from Google Scholar and 286 studies from Scopus were identified through database searching. From a forward search that mostly cited in the references of these works, additional 38 studies were identified through other sources. The search ended in March 2021 with 1,082 records (1044 from the database and 38 from other sources). At the first stage, 115 duplicating studies were removed. After using the selection criteria mentioned above, 23 studies satisfied all the criteria and were selected for the meta-analysis. Excluding reasons for some studies and the flow diagram of the searching, the procedure is shown in Figure 1.

\subsection{Data Coding}

For the reliability of the meta-analysis, it is critical to code the data correctly (Lipsey \& Wilson, 2001). It is recommended to check the coding of the data at least by two different researchers studying in that field. For this reason, other than the author of this article, one more researcher studying Science and Technology Policies coded the data separately. Intercoder reliability can be assessed by standard indices such as Agreement Rate (A.R.), Cohen's Kappa, and Pearson Correlation. The agreement rate is the most straightforward and intuitive among these methods and the most commonly used one (Card, 2012: 76). According to the agreement rate method, the coding of the studies was entirely consistent with the author and independent researcher $(\mathrm{AR}=1)$.

Preliminary controls were made before moving on to the analysis section, which showed two possible outliers (value $\geq 4$ ) for the analysis. After removing the outliers, there were 21 records for the final meta-analysis. Descriptive information and the relative weight of these 21 studies are given in Table 1 .

Table: 1

Descriptive Information and Relative Weight of the Selected Studies

\begin{tabular}{|c|c|c|}
\hline Study Name & Study Level & R.Weight \\
\hline Aldieri et al., 2015 & Firm-level & 4.86 \\
\hline Aldieri et al., 2019 & Sector-level & 4.86 \\
\hline Aubert-Tarby et al., 2017 & Sector-level & 4.87 \\
\hline Barbieri et al., 2018 & Firm-level & 4.85 \\
\hline Bogliacino et al., 2011 & Firm-level & 4.84 \\
\hline Bogliacino et al., 2012 & Sector-level & 4.86 \\
\hline Bogliacino, 2014 & Firm-level & 4.85 \\
\hline Buerger et al., 2012 & Sector-level & 4.81 \\
\hline Feldmann, 2013 & Macro-level & 3.72 \\
\hline Haile et al., 2017 & Firm-level & 4.87 \\
\hline Horbach, 2010 & Firm-level & 4.85 \\
\hline Lachenmaier \& Rottmann, 2011 & Firm-level & 4.87 \\
\hline Matuzeviciute et al., 2017 & Macro-level & 4.33 \\
\hline Meschi et al., 2011 & Firm-level & 4.87 \\
\hline Ni \& Obashi, 2011 & Firm-level & 4.87 \\
\hline Paul \& Lal, 2020 & Sector-level & 4.55 \\
\hline Pellegrino et al., 2018 & Firm-level & 4.84 \\
\hline Piva \& Vivarelli, 2018 & Firm-level & 4.85 \\
\hline Torrecillas et al., 2017 & Macro-level & 4.84 \\
\hline Triguero et al., 2017 & Firm-level & 4.87 \\
\hline Van Roy et al., 2018 & Firm-level & 4.87 \\
\hline
\end{tabular}


In this meta-analysis, the studies consist of three sub-groups according to their study level categorically. 14 firm-level, 6 sector-level, and 3 macro-level studies will be analysed through the categories, and results will be assessed separately.

\section{Results}

\subsection{Common Effect Size}

The main goal is to find a mean effect size of all studies chosen for the analysis. Card (2012) defines the focus on effect sizes as "the whats of meta-analysis". There are many alternative indices to use as an effect size. Among these indices, Cohen's d, Hedges' g, and Glass's index are the most common indices of standardized mean difference (Grissom \& Kim, 2005). These indices are defined by equations 1, 2, and 3.

$$
\begin{aligned}
& \text { Hedge's } g=M^{1}-M^{2} / S_{\text {pooled }} \\
& \text { Cohen's d }=M^{1}-M^{2} / S_{\text {pooled }} \\
& \text { Glass's index g Glass }=M^{1}-M^{2} / S_{1}
\end{aligned}
$$

- $\mathrm{M}^{1}$ and $\mathrm{M}^{2}$ are the means of groups 1 and 2 .

- $\mathrm{S}_{\text {pooled }}$ is the pooled estimate of the population standard deviation.

- $\mathrm{Sd}_{\text {pooled }}$ is the pooled sample standard deviation.

- $\mathrm{S}_{1}$ is the estimate of the population standard deviation from group 1 .

Even with large sample sizes, Hedge's g and Cohen's d will be virtually identical (Card, 2012: 91). Therefore, using Hedge's g or Cohen's in this meta-analysis will not give a far different result. Hedge's g was used in this meta-analysis. In an analysis with the same studies with Cohen's d effect size, the results seem identical. A primary effect size of the selected studies for fixed effect and random effect is in Table 2.

Table: 2

\section{Effect Size for Random and Fixed Effect}

\begin{tabular}{|c|c|c|c|c|c|c|}
\hline Model & Number Studies & Point Estimate & Std. Error & Variance & Lower Limit & Upper Limit \\
\hline Fixed & 21 & 0.232 & 0.002 & 0.000 & 0.227 \\
\hline Random & 21 & 0.527 & 0.174 & 0.030 & 0.237 \\
\hline
\end{tabular}

The mean effect size of the sample in the random-effects model was significant (greater than zero $\mathrm{p}<.01$ ) and computed as 0.53 with a standard error of .17 and the $95 \%$ confidence interval ranges from .19 to .87 . In the fixed-effects model, the effect size was statistically non-significant.

The most critical result gained by meta-analysis is the effect size which represents the power of all studies individually and the overall result for all included studies. Table 3 shows the effect sizes of all studies and a forest plot which is an indispensable part of a metaanalysis. All analyses were made through the Comprehensive Meta-Analysis (CMA Version 3) Software, and the computations on the tables are an output of this software. 
Table: 3

\section{Effect Sizes and Forest Plot for Random Effect Model}

\begin{tabular}{|c|c|c|c|c|}
\hline Stuady Nane & Hatge's 8 & $\begin{array}{l}\text { Lone } \\
\text { Liwis }\end{array}$ & $\begin{array}{c}\text { UPrer } \\
\text { Lindt }\end{array}$ & value \\
\hline Aldieri et al., 2015 & 2.05 & 1.97 & 2.13 & 0.00 \\
\hline Aldieri et al, 2019 & -0.01 & -0.09 & 0.09 & 0.98 \\
\hline Aubert-Tanby et al., 2017 & -0.75 & -0.77 & -0.73 & 0.00 \\
\hline Barbieriet al., 2018 & -1.48 & -1.58 & -1.37 & 0.00 \\
\hline Bogliacino et al., 2011 & -1.28 & -1.40 & -1.17 & 0.00 \\
\hline Bogliacino et al., 2012 & -0.20 & -0.26 & -0.14 & 0.00 \\
\hline Bogliacino, 2014 & 2.71 & 2.61 & 2.81 & 0.00 \\
\hline Buerger et al, 2012 & 0.76 & 0.59 & 0.94 & 0.00 \\
\hline Feldmann, 2013 & 2.93 & 2.06 & 3.79 & 0.00 \\
\hline Haile et al, 2017 & 0.54 & 0.50 & 0.59 & 0.00 \\
\hline Horbach, 2010 & 0.05 & -0.04 & 0.14 & 0.30 \\
\hline Lachenmaier \& Rotmann, 2011 & -0.12 & -0.15 & -0.08 & 0.00 \\
\hline Matuzeviciute et al., 2017 & -0.01 & -0.56 & 0.53 & 0.96 \\
\hline Meschi et al., 2011 & 0.31 & 0.30 & 0.32 & 0.00 \\
\hline Ni \& Obashi, 2011 & 0.21 & 0.20 & 0.21 & 0.00 \\
\hline Paul \& Lal, 2020 & 1.13 & 0.72 & 1.54 & 0.00 \\
\hline Pellegrino et al., 2018 & -0.11 & -0.22 & 0.01 & 0.07 \\
\hline Piva \& Vivarelli, 2018 & 0.64 & 0.53 & 0.75 & 0.00 \\
\hline Torrecillas et al., 2017 & 1.04 & 0.91 & 1.16 & 0.00 \\
\hline Triguero et al., 2017 & -0.51 & -0.55 & -0.47 & 0.00 \\
\hline Van Roy et al., 2018 & 3.69 & 3.66 & 3.73 & 0.00 \\
\hline Random & 0.53 & 0.19 & 0.87 & 0.00 \\
\hline
\end{tabular}

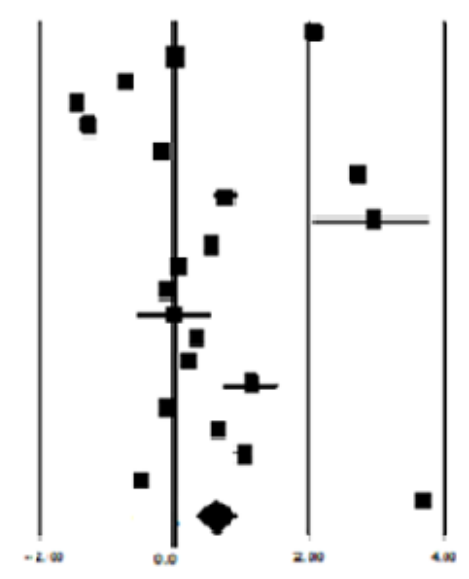

The most common models used in meta-analyses are fixed effect and random effect models. Although using a random effect model in meta-analyses in social sciences is common, it is better to check some assumptions. The critical difference between fixed effect and random effect is that "the single parameter of the fixed-effects model, the single population effect size ( $\theta$ ), is decomposed into two parameters (the central tendency and study deviation, $\mu$, and $\xi i$ ) in the random-effects model" (Card, 2012: 233). According to Card (2012), "The challenge of the random-effects model is to determine how much of the variability in each study's deviation from this mean is due to the distribution of population effect sizes".

To determine whether to use a fixed-effect or random-effect model, homogeneity (heterogeneity) is one of the significant factors. In the following section on heterogeneity tests, it is evident that the data is heterogeneous. The other one is the relative weight of the studies. In the random-effect model relative weight of the studies seems close to each other (see Table 1). But in a fixed-effect model, the studies seem very fluxional, and the relative weight of a few studies are far more than the others. Another factor in deciding the model in meta-analysis is the goal of your study. Results from fixed-effects models are limited to only the chosen studies in your meta-analysis, whereas the random-effect model allows more generalizable conclusions (Card, 2012: 250).

All the assumptions show us random effect model is the correct preference for this analysis. The $\mathrm{p}$-value of the random effect model $(\mathrm{p}=.00)$ supports the significance of the analysis. The mean effect size was computed as 0.53 the $95 \%$ confidence interval ranges from .19 to .87 . A common way of interpreting effect sizes is to consider them as "small (= $.2)$, medium (= .5), and large (= .8)" (Lakens, 2013: 11). This value (0.53) is medium effect 
size, and it represents a positive relationship between technology and employment. When we consider it presents the mean effect of all studies included in the meta-analysis, it is a valuable conclusion that suggests technology boosts employment. The common prejudice about technology is its job-saving effect, but this analysis claims that its job-creating effect is more dominant than the job-saving effect.

\subsection{An ANOVA for Sub-group Analyses}

In the meta-analysis, it is beneficial to use an ANOVA test to see the effect size and heterogeneity separately in sub-groups. For this purpose, the test was conducted on subgroups to see a difference between the effect size and sub-group heterogeneity. The moderator was the level of the studies such as macro-level studies, firm-level studies, and sector-level studies. In the ANOVA, out of 21 studies included in the meta-analysis 13 of them were firm-level, 3 were macro-level, and 5 were sector-level studies.

Firm-level and macro-level studies seem significant $(\mathrm{p}=.02$ and $\mathrm{p}=.03)$, but sectorlevel studies seem non-significant $(\mathrm{p}=.50)$ statistically. The overall effect of the studies was significant statistically, and the overall effect size of the 21 studies was 0.42 , which is close to medium size. The sub-group effect size of firm-level studies in the ANOVA was computed as 0.52 , the $95 \%$ confidence interval ranges from .09 to .94 , and the z-value is 2.37. The effect size for the macro-level sub-group is 1.25 , which is a large effect, and the $95 \%$ confidence interval ranges from .13 to 2.37. The effect size of sector-level studies was very small $(.16)$ and non-significant $(\mathrm{p}=.50)$.

\section{Table: 4}

\section{Effect Sizes for Sub-groups}

\begin{tabular}{|c|c|c|c|c|c|c|c|}
\hline Study Level & $\mathrm{N}$ & Effect Size & Standard Error & Lower Limit & Upper Limit & Z-Value & p-Value \\
\hline Firm-Level & 13 & 0.52 & 0.22 & 0.09 & 0.94 & 2.37 & 0.02 \\
\hline Macro-Level & 3 & 1.25 & 0.57 & 0.13 & 2.37 & 2.19 & 0.03 \\
\hline Sector-Level & 5 & 0.16 & 0.24 & 0.40 & 0.93 & 0.67 & 0.50 \\
\hline Overall & 21 & 0.42 & 0.16 & 0.12 & 0.72 & 2.71 & 0.01 \\
\hline
\end{tabular}

\subsection{Homogeneity versus Heterogeneity}

It is vital to see if the data is heterogeneous in a meta-analysis, and there are a few indices to check. Statistic Q is one of the common ways to control heterogeneity of the effect sizes. The equation for statistic Q is below Equation 3 (Card, 2012: 185).

$$
Q=\sum\left(w_{i}\left(E S_{i}-\overline{E S}\right)^{2}\right)=\sum\left(w_{i} E S_{i}^{2}\right)-\left(\sum\left(w_{i} E S_{i}\right)\right)^{2} / \sum w_{i} \mathrm{dr}=\mathrm{k}-1
$$

- $\mathrm{w}_{\mathrm{i}}$ is the weight of study $\mathrm{i}$.

- E. $S_{\cdot \mathrm{i}}$ is the effect size estimate from study $i$.

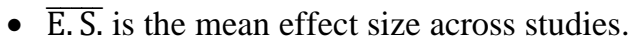

- $\mathrm{K}$ is the number of studies.

$Q$ statistic is distributed as $\chi 2$ with $d f=k-1$ under the null hypothesis of homogeneity. When I look up the chi-square distribution table, the $\mathrm{Q}$ value exceeds the 20 
degrees of freedom and .05 confidence interval $(d f=20, \chi 2(.05)=31.41)$. It proves that the effect sizes are heterogeneous (See Table 5).

Table: 5

Heterogeneity/ Homogeneity for Common Effect Size

\begin{tabular}{|l|c|c|c|}
\hline Q-value & Df $(\mathrm{Q})$ & P-value & $\mathrm{I}^{2}$ \\
\hline 64493.72 & 20 & 0.00 & 99.97 \\
\hline
\end{tabular}

Another valuable index for heterogeneity is the $I^{2}$ index which shows the variability among the effect sizes. Huedo-Medina et al. (2006) interpret $I^{2}$ as $" \approx 25 \%$ small, $\approx 50 \%$ medium, and $\approx 75 \%$ large" amount of heterogeneity. $I^{2}(99.97)$ for this meta-analysis showed a large amount of heterogeneity. Also, the p-value (0.00) suggests heterogeneity for the data.

Table: 6

\section{Heterogeneity/ Homogeneity for Sub-groups}

\begin{tabular}{|l|c|c|c|c|}
\hline Sub-group & Q-value & Df (Q) & P-value & $\mathrm{I}^{2}$ \\
\hline Firm-level & 52090.97 & 12 & 0.00 & 99.97 \\
\hline Macro-level & 32.583 & 2 & 0.00 & 93.86 \\
\hline Sector-level & 874.59 & 4 & 0.00 & 99.54 \\
\hline
\end{tabular}

Heterogeneity tests for sub-group analyses also confirm effect sizes of all sub-groups are heterogeneous. The results are respectively, Q statistic (52090.97, 32.583, 874.59), pvalue (0.00 for all sub-groups) and $I 2$ index were $(99.97,93.86,99.54)$.

\subsection{Publication Bias}

The reality and reliability of the effect sizes mostly hinge upon publication bias in meta-analyses. It refers to the possibility that studies finding negative results are less likely to be published. The presence of publication bias means that the studies included in the metaanalysis might not be representative of all studies on the topic. In other words, the available results likely show a stronger effect size than if all studies were considered (Card, 2012: 258).

Table: 7

Fail-safe N Test

\begin{tabular}{|l|c|}
\hline Z-value for observed studies & 78.47 \\
\hline P-value for observed studies & 0.00 \\
\hline Alpha & 0.05 \\
\hline Tails & 2.00 \\
\hline Z for alpha & 1.95 \\
\hline Number of observed studies & 21 \\
\hline Number of missing studies that would bring p-value to >alpha & 3643 \\
\hline
\end{tabular}

In this meta-analysis, three different most common tests for publication bias were conducted. The first one was the "fail-safe $N$ " test proposed by Rosenthal (1979). The number of missing studies that would bring a p-value greater than alpha was 3643 in the failsafe $\mathrm{N}$ test at .05 confidence level (see Table7). $5 \mathrm{n}+10$ formula (Fragkos et al., 2014) equals 
110 , and 3643 is much greater than this value. So, the fail-safe $\mathrm{N}$ test confirmed there was no publication bias.

Duval \& Tweedie's (2000) "trim and fill” method shows that none of the studies was trimmed, and the observed values and adjusted values were identical (see Table 8 ). This test confirmed the result of the fail-safe $\mathrm{N}$ test, and in short, it suggested there was no publication bias.

Table: 8

Duval and Tweedie's Trim and Fill Test

\begin{tabular}{|c|c|c|c|c|c|c|c|c|}
\hline & & \multicolumn{3}{|c|}{ Fixed Effects } & \multicolumn{3}{c|}{ Random Effects } & Lower \\
\hline & $\begin{array}{c}\text { Studies } \\
\text { Trimmed }\end{array}$ & $\begin{array}{c}\text { Point } \\
\text { Estimate }\end{array}$ & $\begin{array}{c}\text { Lower } \\
\text { Limit }\end{array}$ & $\begin{array}{c}\text { Upper } \\
\text { Limit }\end{array}$ & $\begin{array}{c}\text { Point } \\
\text { Estimate }\end{array}$ & $\begin{array}{c}\text { Limit } \\
\text { Limit }\end{array}$ & Q Value \\
\hline $\begin{array}{c}\text { Observed } \\
\text { values }\end{array}$ & - & 0.232 & 0.227 & 0.237 & 0.529 & 0.187 & 0.870 & 64493.88 \\
\hline Adjusted values & 0 & 0.232 & 0.227 & 0.237 & 0.529 & 0.187 & 0.870 & 64493.88 \\
\hline
\end{tabular}

Egger et al. (1997) proposed a test to estimate the asymmetry of the funnel plot. In Egger's regression, if the p-value is less than 0.05, it implicates publication bias (Jin et al., 2014). Egger's regression test of the studies included in the meta-analysis gave p-value= 0.31 (1-tailed) and $p$-value $=0.63$. So, the test confirmed the previous publication bias test results and showed there was no publication bias.

Table: 9

Egger's Regression Intercept Test

\begin{tabular}{|l|c|}
\hline Intercept & 7.48 \\
\hline Standard error & 15.29 \\
\hline 95\% lower limit (2-tailed) & -24.53 \\
\hline 95\% upper limit (2-tailed) & 39.49 \\
\hline t-value & 0.49 \\
\hline Df & 19.00 \\
\hline P-value (1-tailed) & 0.32 \\
\hline P-value (2-tailed) & 0.63 \\
\hline
\end{tabular}

\section{Conclusion and Policy Remarks}

The effects of technology on the economy and especially on employment have been discussed for many years. The increase in productivity provided by technology in production and the corresponding decrease in costs and prices is a generally accepted result. However, the situation is very different when it comes to the effects of technology on employment. An important part of the studies in the literature is micro econometric studies conducted at firmlevel and sector-level. However, the number of macro studies that can show an overall effect on the economy is very few. Moreover, most macro studies, which are few, could not reach statistically significant findings. There are some explicit situations in micro econometric studies. For example, there is a consensus in the literature that product innovation positively affects employment, and that process innovation has a negative effect. Similarly, in most of the studies conducted at the micro-level, it is seen that R\&D expenditures and patent numbers have a positive relationship with employment. 
Technological innovations positively affect the economy with cost reductions resulting from productivity gains. The increase in welfare, called the increase in GDP, contributes to the country's general economy. However, machines or robots doing the work previously done by humans bring about changes in the traditional production approach. Today's skill requirements and qualifications sought in workers are different than in the past, and it would probably be far different in the next production revolution. However, reducing automation to the level of capturing human work by machines would be a somewhat biased and inadequate approach. That is to say; technological innovations provide the emergence of many new products and sectors with the spillover effect. Invention, design, maintenance, repair of machines, increasing product variety, and production increase with decreasing costs are just some of the advantages of technology. The critical point is whether a sufficient number of jobs in new production sectors and new lines of work are provided for workers replaced by machines. In other words, if the newly created jobs are on par with the disappeared jobs and the workers successfully provide the necessary orientation, there is no question of being unemployed due to technological progress.

In this paper, a new analysis has been made using econometric studies published between 2010 and 2021 on the technology-employment relationship. In this study, the metaanalysis method was used, and a more comprehensive overall effect size was obtained independently from the results of other studies. Hedge's $g=0.53$, this effect size is medium level, indicating that technology positively affects employment. This situation shows that the jobs created by technology are more than the jobs it destroys. In the process Schumpeter refers to as creative destruction, innovations have opened the door to more efficient technologies and processes. According to the findings of this paper, employees who were dismissed during the automation process were able to find jobs for themselves in new jobs that emerged thanks to technology. However, this result is only limited to the empirical findings of this paper. Analysis in different sectors, regions, and firms could give any different effects of the technology.

The impact of technology on human labour cannot yet be measured clearly. However, the positive effects of technology in terms of job-saving and productivity increase should not be ignored. Although technology may cause temporary unemployment due to its jobsaving effect, this effect on employment can be minimized with compensation mechanisms. In innovation policies, it should focus on productivity increase rather than labour-saving and compensate for the negative effects on the workforce with the increase in the welfare level created by technology.

\section{References}

Acemoglu, D. \& P. Restrepo (2020), "Robots and Jobs: Evidence from U.S. Labor Markets", Journal of Political Economy, 128(6), 2188-2244.

Aguilera, A. \& M.G.R. Barrera (2016), "Technological Unemployment: An Approximation to the Latin American Case”, AD-Minister, 29, 59-78. 
Aldieri, L. et al. (2015), "R\&D spillovers and employment: a micro-econometric analysis", MPRA Paper No. 67269.

Aldieri, L. et al. (2019), "Spoils of Innovation? Employment Effects of R\&D and Knowledge Spillovers in Finland", Economics of Innovation and New Technology, 1-15.

Armstrong, S. (2014), Smarter Than Us: The Rise of Machine Intelligence, Berkeley: Machine Intelligence Research Institute.

Arntz, M. et al. (2016), "The Risk of Automation for Jobs in OECD Countries: A Comparative Analysis”, OECD Social, Employment and Migration Working Papers, No. 189, OECD Publishing, Paris.

Aubert-Tarby, C. et al. (2017), "The Impact of Technological Change on Employment: The Case of Press Digitisation”, Technological Forecasting \& Social Change, 128, 36-45.

Autor, D.H. \& D. Dorn (2013), "The Growth of Low-Skill Service Jobs and The Polarization of The Us Labor Market”, American Economic Review, 103, 1553-97.

Barbieri, L. et al. (2018), "R\&D, Embodied Technological Change, and Employment: Evidence from Italian Microdata", Industrial and Corporate Change, 28(1), 203-18.

Bimber, B. (1990), "Karl Marx and The Three Faces of Technological Determinism”, Social Studies of Science, 20(2), 333-351.

Bogliacino, F. \& M. Pianta (2010), "Innovation and Employment: A Reinvestigation Using Revised Pavitt Classes", Research Policy, 39, 799-809.

Bogliacino, F. et al. (2011) "R\&D and Employment: Some Evidence from European Microdata", IZA Discussion Paper No. 5908.

Bogliacino, F. et al. (2012), "R\&D and Employment: An Application of the LSDVC Estimator Using European Microdata", Economics Letters, 116, 56-59.

Bogliacino, F. (2014), "Innovation and employment: A firm level analysis with European R\&D Scoreboard data”, Economia, 15(2), 141-54.

Brynjolfsson, E. \& A. McAfee (2014), The Second Machine Age: Work, Progress, and Prosperity in a Time of Brilliant Technologies, New York: W.W. Norton.

Buerger, M. et al. (2012), "Regional Dynamics of Innovation: Investigating the Co-evolution of Patents, Research and Development (R\&D), and Employment", Regional Studies, 46(5), 565-82.

Campa, R. (2018), Still Think Robots Can't Do Your Job. Essays on Automation and Technological Unemployment, Roma: D Editore.

Cang, Y. (2017), “A Deep Dive into Technological Unemployment: A State-Level Analysis on the Employment Effect of Technological Innovations", Senior Thesis, Claremont McKenna College.

Card, N.A. (2012), Applied Meta-Analysis for Social Science Research, New York, NY: Guilford Press.

Chang, J.H. \& P. Huynh (2016), "ASEAN in transformation. The Future of jobs at risk in automation, International Labour Office (ILO), Bureau for Employers' Activities”, Working Paper No 9.

Cirillo, V. et al. (2018), “Technology and Occupations in Business Cycles”, Sustainability, 10(463), $1-25$. 
Dachs, B. \& B. Peters (2014), "Innovation, Employment Growth, and Foreign Ownership of Firms", Research Policy, 43(1), 214-32.

Dağl1, İ. \& V. Karaçadır (2021), “İleri Teknoloji İhracatı ve Ekonomik Büyüme İlişkisine Genel Bir Bakış: Bir Meta-Analiz Çalışması”, Kafkas Üniversitesi İIBF Dergisi, 12(23), 160-180.

Delgado, P. et al. (2018), "Don't Throw Away Your Printed Books: A Meta-Analysis on The Effects of Reading Media on Reading Comprehension", Educational Research Review, 25, 23 38.

Duval, S. \& R. Tweedie (2000), “Trim and Fill: A Simple Funnel-Plot-Based Method of Testing and Adjusting for Publication Bias in Meta-Analysis", Biometrics, 56(2), 455-63.

Edwards, A.V. (2015), Digital is Destroying Everything: What the Tech Giants Won't Tell You about how Robots, Big Data, and Algorithms are Radically Remaking Your Future, Rowman \& Littlefield.

Egger, M. et al. (1997), "Bias in Meta-Analysis Detected by a Simple Graphical Test”, Bmj, 315(7109), 629-34.

Evangelista, R. \& A. Vezzani (2011), “The Impact of Technological and Organizational Innovations on Employment in European Firms", Industrial and Corporate Change, 21(4), 871-99.

Evangelista, R. \& M. Savona (2002), "The Impact of Innovation on Employment in Services: Evidence from Italy", International Review of Applied Economics, 16, 309-18.

Evangelista, R. et al. (2014), “The Economic Impact of Digital Technologies in Europe”, Economics of Innovation and New Technology, 23(8), 802-24.

Falk, M. (2015), "Employment Effects of Technological and Organizational Innovations: Evidence Based on Linked Firm-Level Data for Austria", Jahrbücher Für Nationalökonomie Und Statistik, 235(3), 268-285.

Feldmann, H. (2013), “Technological Unemployment in Industrial Countries”, Journal of Evolutionary Economics, 23, 1099-1126.

Ford, M. (2015), Rise of the Robots: Technology and the Threat of Mass Unemployment, New York: Basic Books.

Fragkos, K.C. et al. (2014), "Publication Bias in Meta-Analysis: Confidence Intervals for Rosenthal's Fail-Safe Number", International Scholarly Research Notices, 2014, 825383.

Frey C.B. \& M.A. Osborne (2017), “The Future of Employment: How Susceptible Are Jobs to Computerisation?", Technological Forecasting and Social Change, 114, 254-80.

Greenan, N. \& D. Guellec (2000), “Technological Innovation and Employment Reallocation”, Labour, 14(4), 547-90.

Grissom, R.J. \& J.J. Kim, (2005), Effect Sizes for Research: A Broad Practical Approach, Mahwah, NJ: Erlbaum.

Haile, G. et al. (2017), "Imported Technology and Manufacturing Employment in Ethiopia", Eurasian Business Review, 7(1), 1-23.

Hall, B.H. et al. (2008), "Employment, Innovation, and Productivity: Evidence from Italian Microdata", Industrial and Corporate Change, 17(4), 813-39.

Harrison, R. et al. (2014), "Does Innovation Stimulate Employment? A Firm-Level Analysis Using Comparable Micro-Data from Four European Countries", International Journal of Industrial Organization, 35, 29-43. 
Horbach, J. (2010), “The Impact of Innovation Activities on Employment in the Environmental Sector - Empirical Results for Germany at the Firm Level", Jahrbücher Für Nationalökonomie Und Statistik, 230(4), 403-19.

Huedo-Medina, T.B. et al. (2006), "Assessing Heterogeneity in Meta-Analysis: $Q$ statistic or $I 2$ index?”, Psychological Methods, 11, 193-206.

Huo, J. \& H. Feng (2010), "The Political Economy of Technological Innovation and Employment”, Comparative Political Studies, 43(3), 329-52.

ILO (2016), Technological Changes and Work in the Future: Making Technology Work for All, The Future of Work the Centenary Initiative, International Labour Office, Issue Note Series 1.

ILO (2018), The Impact of Technology on the Quality and Quantity of Jobs, The Future of Work, International Labour Office, Issue Brief Series No 6. 241.

ILO (2020), World Employment and Social Outlook: Trends 2020, Geneva: International Labour Office.

ILO (2021), World Employment and Social Outlook: Trends 2021, Geneva: International Labour Office.

Jin, ZC. et al. (2014), “A Modified Regression Method to Test Publication Bias in Meta-Analyses with Binary Outcomes", BMC Med Res Methodol, 14, 132.

Kelly, K. (2016), The Inevitable: Understanding the 12 Technological Forces that will Shape Our Future, New York, New York: Viking.

Kim, Y.S.G. et al. (2021), “Writing Instruction Improves Students' Writing Skills Differentially Depending on Focal Instruction and Children: A Meta-Analysis for Primary Grade Students", Educational Research Review, 34, 100408.

Krousie, C. (2018), "Technological Unemployment in the United States: A State-Level Analysis", Major Themes in Economics, 20(6), 87-101.

Kurzweil, R. (2000), The Age of Spiritual Machines: When Computers Exceed Human Intelligence, Penguin.

Kwon, S.J. et al. (2015), "Innovation Activities and the Creation of New Employment: An Empirical Assessment of South Korea's Manufacturing Industry”, Social Science Information, 54(3), 354-68.

Lachenmaier, S. \& H. Rottmann (2011), "Effects of Innovation on Employment: A Dynamic Panel Analysis", International Journal of Industrial Organization, 29, 210-20.

Lakens, D. (2013), "Calculating and Reporting Effect Sizes to Facilitate Cumulative Science: A Practical Primer for T-Tests and ANOVAs", Frontiers in Psychology, 4, 863.

Leonhard, G. (2016), Technology vs. Humanity: The Coming Clash between Man and Machine, FutureScapes.

Leontief, W. (1979), “Is Technological Unemployment Inevitable?", Challenge, 22(4), 48-50.

Lipsey, M.W. \& D.B. Wilson (2001), Practical Meta-Analysis, Applied Social Research Methods Series, Vol. 49, Thousand Oaks, CA: Sage publications.

Matuzeviciute, K. et al. (2017), "Do Technological Innovations Affect Unemployment? Some Empirical Evidence from European Countries", Economies, 5(48), 1-19. 
Meriküll, J. (2008), “The Impact of Innovation on Employment: Firm- and Industry-level Evidence from Estonia”, Eesti Pank Bank of Estonia, Working Paper Series, 1/2008.

Meschi, E. et al. (2011), "Trade, Technology and Skills: Evidence from Turkish Microdata", Labour Economics, 18, 60-70.

Morrison Paul, C.J. \& D.S. Siegel (2001), “The Impacts of Technology, Trade and Outsourcing on Employment and Labor Composition”, Scandinavian Journal of Economics, 103(2), 24164.

Ni, B. \& A. Obashi (2021), "Robotics Technology and Firm-Level Employment Adjustment in Japan", Japan and the World Economy, 57, 101054.

Paul, S. \& K. Lal (2020), “Technology Intensity and Employment in the Indian Economy", Arthaniti: Journal of Economic Theory and Practice, 0976747919895326.

Pellegrino, G. et al. (2018), "R\&D, Embodied Technological Change and Employment: Evidence from Spain”, GLO Discussion Paper, No. 214.

Peters, B. (2005), "Employment Effects of Different Innovation Activities: Microeconometric Evidence", ZEW Centre for European Economic Research, Discussion Paper 04-073.

Pini, P. (1995), "Economic Growth, Technological Change and Employment: Empirical Evidence for a Cumulative Growth Model with External Causation for Nine OECD Countries: 1960-1990", Structural Change and Economic Dynamics, 6, 185-213.

Piva, M. \& M. Vivarelli (2018), "Is Innovation Destroying Jobs? Firm-Level Evidence from the E.U.”, Sustainability, 10(1279), 1-16.

Ricardo, D. (1817), The Principles of Political Economy \& Taxation, Kitchener, Canada: Batoche Books.

Rosenthal, R. (1979), “The File Drawer Problem and Tolerance for Null Results”, Psychological Bulletin, 86, 638-41.

Schumpeter, J.A. (1939), Business Cycles: A Theoretical, Historical, and Statistical Analysis of the Capitalist Process, (ed. Rendigs Fels), New York and London: McGraw-Hill.

Schumpeter, J.A. (1943), Capitalism, Socialism and Democracy, New York: Harper Collins.

Schwab, K. (2016), The Fourth Industrial Revolution, Currency.

Simonetti, R. et al. (2000), "Modelling the Employment Impact of Innovation", in: The Employment Impact of Innovation: Evidence and Policy (ed. Pianta \& Vivarelli), Routledge, 26-46.

Sinclair, P.J.N. (1981), "When will Technical Progress Destroy Jobs?”, Oxford Economics Paper, 31, 1-18.

Smith, A. (1776), An Inquiry into The Nature and Causes of The Wealth of Nations, (Edited with an Introduction, Notes, Marginal Summary and an Enlarged Index by Edwin Cannan), London: Methuen. 1904.

Smolny, W. (1998), "Innovations, Prices and Employment”, Journal of Industrial Economics, 46(3), 359-380.

Tancioni, M. \& R. Simonetti (2002), “A Macroeconometric Model for The Analysis of The Impact of Technological Change and Trade on Employment", Journal of Interdisciplinary Economics, 13, 185-221. 
Torrecillas, C. et al. (2017), “The Dual Role of R\&D Expenditures in European Union's Member States: Short- and Long-Term Prospects", Innovation: The European Journal of Social Science Research, 30(4), 433-54.

Triguero, Á. et al. (2017), "Environmental Innovation and Employment: Drivers and Synergies", Sustainability, 9(2057), 1-12.

Van Reenen, J. (1997), "Employment and Technological Innovation: Evidence from U.K Manufacturing Firms", Journal of Labor Economics, 15(2), 255-84.

Van Roy, V. et al. (2018), “Technology and Employment: Mass Unemployment or Job Creation? Empirical Evidence from European Patenting Firms", Research Policy, 47, 1762-76.

Vivarelli, M. (1995), The Economics of Technology and Employment: Theory and Empirical Evidence, Cheltenham: Edward Elgar.

WEF (2017), The Future of Jobs and Skills in the Middle East and North Africa, World Economic Forum, May 2017

Yaman, H. (2020), “Araştırma Geliştirme (Ar-Ge) Faaliyetleri ile Ekonomik Büyüme İlişkisinin Meta Analiz Yöntemiyle Değerlendirmesi”, Anemon Muş Alparslan Üniversitesi Sosyal Bilimler Dergisi, 8(4), 1247-1254. 
Dağl1, İ. (2021), "Will Workers be Unemployed Because of Robots? A MetaAnalysis on Technology and Employment", Sosyoekonomi, 29(50), 485-501. 